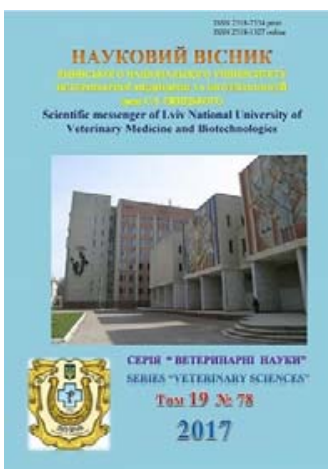

Науковий вісник Львівського національного університету ветеринарної медицини та біотехнологій імені С.З. Гжицького

Scientific Messenger of Lviv National University of Veterinary Medicine and Biotechnologies

doi:10.15421/nvlvet7829

ISSN 2518-7554 print

ISSN 2518-1327 online

http://nvlvet.com.ua/

УДК 636.5:619:576.8:619:616.981.459:619:616.995.132

\title{
Вплив умовно патогенної мікрофлори на розвиток патологічного процесу за пастерельозно-аскаридіозного мікст захворювання птиці
}

\author{
В.М. Плис \\ inst_zerna@ukr.net \\ Державна установа Інститут зернових культур Наиіональної академії аграрних наук України, \\ вул. Дзержинського, 14, м. Дніпро, 49027, Украӥна
}

\begin{abstract}
В статті викладено результати патолого-анатомічного розтину трупів птиці і бактеріологічних досліджень патологічного матеріалу, відібраного від загиблої птичі. Встановлено, щео патологічний прочес при пастерельозно-аскаридіозному мікст захворюванні птиці посилювався за рахунок ускладнення його умовно патогенною мікрофлорою, а саме Escherichia coli, яка складала 85,4\% від усіх виділених мікроорганізмів.

Найчастіше виділення умовно патогенної мікрофлори за пастерельозно-аскаридіозного мікст захворювання відмічали навесні до 41,7\%. Патолого-анатомічні зміни за пастерельозно-аскаридіозного мікст захворювання, ускладненого умовно патогенною мікрофлорою, були нехарактерними: виснаження, кон'юнктивіт, виділення із носової порожнини мутного слизу, гідроперикардит, катаральна пневмонія, перигепатит, спленіт, катарально-геморагічний ентероколіт, геморагічний дуоденіт, клоацит, пір'я скуйовджене, тьмяне, навколо клоаки забруднене послідом темно-сірого кольору, інколи з домішками фібрину, суглоби потовщені, в суглобовій піхві скопичення ексудату солом'яно-жовтого кольору. У півнів інколи відмічали ціаноз гребеня, в індиків - ціанотичність похідних шкіри голови, голубів і папуг - інтенсивне виснаження, збільшення селезінки в два рази порівняно з нормою.

Найчастіше виділяли умовно патогенну мікрофлору із паренхіматозних органів: серия, печінки, селезінки та червоного кісткового мозку. Тому виділені патогенні мікроорганізми відіграють важливу роль у розвитку і ускладненні патологічного процесу за пастерельозно-аскаридіозного мікст захворювання у птиці.

Ключові слова: умовно патогенна мікрофлора, птиия, мікст захворювання, бактерії, гельмінти, патологічний матеріал, бактеріологічні дослідження.
\end{abstract}

\section{Влияние условно патогенной микрофлоры на развитие патологического процесса при пастереллезно-аскаридиозном микст заболевании птицы}

\author{
В.Н. Плыс \\ inst_zerna@mail.ru
}

Государственное учреждение Институт зерновых культур Национальной академии аграрных наук Украины, ул. Дзержинского, 14, г. Днепр, 49027, Украина

В статье изложены результаты патологоанатомического вскрытия трупов птицы и бактериологических исследований патологического материала, отобранного от погибшей птиџы. Установили, что патологический процесс при пастереллезно-аскаридиозном микст заболевании птиць усиливается за счет осложнения его условно патогенной микрофлорой - Escherichia coli, которая составляет 85,4\% от всех выделенных микроорганизмов.

Чаще всего выделение условно патогенной микрофлоры при пастереллезно-аскаридиозном микст заболевании отмечали весной - до 82,4\%.Патологоанатомические изменения при пастереллезно-аскаридиозном микст заболевании, осложненном условно патогенной микрофлорой, были нетипичными: истощение, конъюнктивит, выделение из носовой полости мутной слизи, гидроперикардит, катаральная пневмония, перигепатит, спленит, катарально-геморрагический энтероколит, гемо-

\section{Citation:}

Plys, V.M. (2017). The influence conditionally pathogenic microflora on the development of pathological processes at the mixed pasteurellosis and ascaridosis diseases of poultry. Scientific Messenger LNUVMB, 19(78), 146-149. 
ррагический дуоденит, клоачит, перья взъероченные, тусклые, возле клоаки испачканы пометом темно-серого ивета, иногда с примесью фибрина, суставы утолщены, в суставном влагалище скопление экссудата соломенно-желтого иявета. У петухов иногда наблюдали цианоз гребня, у индюков - цчиантичность производных кожи головы, голубей и попугаев выраженное истощение, увеличение селезенки в два раза от физиологической нормы.

Чашце всего выделяли условно патогенную микрофлору из паренхиматозных органов: сердия, печени, селезёнки и красного костного мезга. Поэтому выделенные патогенные микроорганизмы играют важную роль в развитии и осложнении патологического прочесса при пастереллезно-аскаридиозном микст заболевании птицьь.

Ключевые слова: условно патогенная микрофлора, птица, микст заболевание, бактерии, гельминты, патологический материал, бактериологические исследования.

\title{
The influence conditionally pathogenic microflora on the development of pathological processes at the mixed pasteurellosis and ascaridosis diseases of poultry
}

\author{
V.M. Plys \\ inst_zerna@mail.ru \\ State Institute of crops National Academy of Agrarian Sciences of Ukraine, \\ Dzerzhinsky Str., 14, Dnipro, 49027, Ukraine
}

The article presents the results of autopsy dead of poultry and bacteriological studies of pathological material confiscation of dead birds. It was established that the pathological process at the mixed pasteurellosis and ascaridosis diseases is enhanced by the complications its conditioned pathogenic microflora, ie Escherichia coli, which amounts to $85.4 \%$ of all the isolated microorganisms.

In most cases the selection of conditionally pathogenic microflora in the mixed pasteurellosis and ascaridosis disease observed in the spring to $82.4 \%$. Pathological changes at he mixed pasteurellosis and ascaridosis disease complicated by conditionally pathogenic microflora were atypical: exhaustion, conjunctivitis, allocation from the nose muddy mucus hydropericarditis, catarrhal pneumonia, perihepatitis, splenitis, catarrhal hemorrhagic enterocolitis, hemorrhagic duodenitis, ruffled feathers, near the cloaca soiled dark gray of the droppings, sometimes mixed with fibrin, are thickened joints, in articular vagina accumulation of exudate straw-yellow color. Sometimes at roosters observed cyanosis of the comb, turkeys - cyanotic head skin, pigeons and parrots - expressed exhaustion, enlargement of the spleen twice from the physiological norm.

In most cases were isolated conditionally pathogenic microflora of parenchymal organs: heart, liver, spleen and bone pulp. Because isolated pathogens play an important role in the development and aggravation of the pathological process at he mixed pasteurellosis and ascaridosis disease of poultry.

Key words: conditionally pathogenic microflora, poultry, mixed of disease, bacteria, worms, pathological material, bacteriological tests.

\section{Вступ}

Птахівництво - одна із найбільш високопродуктивних галузей тваринництва. Збільшення виробництва продуктів птахівництва, поліпшення їхньої якості, зниження вартості яєць і м'яса птиці пов'язано з інтенсифікацією галузі (Korovin, 1995; Herman, 2002; Korniienko et al., 2012; Berezovskyi, 2012).

Пастерельозно-аскаридіозне мікст захворювання птиці - широко розповсюджена хвороба, яка наносить значні економічні збитки птахівництву. Умовно патогенна мікрофлора відіграє важливу роль у патологічному процесі цієї асоціації, а саме ослаблює і без того ослаблену імунну резистентність організму птиці, ускладнює патогенез та поглиблює патологічний процес (Bondarenko, 1999; Plys and Shendryk, 2014; Plys and Fotina, 2014; Plys, 2017).

Мікст захворювання при впливі умовно патогенної мікрофлори можуть перебігати в септичній, респіраторній та ентеротоксичній формі, схожі за симптомокомплексом і патолого-анатомічними змінами. Умовно патогенна мікрофлора часто ускладнює перебіг вірусних, бактеріальних, паразитарних та незаразних хвороб і вони протікають у вигляді мікст захворювань. Перебіг змішаних інфекцій буває тяжким, а симптоми - нетиповими і патолого-анатомічні зміни - стертими.
Тому в будь-якому випадку заключний діагноз встановлюють за результатами лабораторних досліджень: серологічних, вірусологічних, бактеріологічних, біологічних, гельмінтокопрологічних та біохімічних. Проводиться виділення та ідентифікація збудника за біохімічними і серологічними властивостями, а також визначення його патогенності (Akulov, 1978; Labinskaja, 1978; Bajdevljatov et al., 1980; Hult et al., 1997; Golovko et al., 2007; Apatenko, 2009).

\section{Матеріал та методи досліджень}

Дослідження проводили впродовж 2013-2015 pp. на базі Державної установи Інститут сільського господарства степової зони Національної академії аграрних наук України в лабораторії ветеринарної медицини, кафедрі паразитології та ветеринарно-санітарної експертизи Дніпропетровського державного аграрноекономічного університету, приватному секторі і агроформуваннях різних форм власності Дніпропетровської, Запорізької, Полтавської, Миколаївської та Вінницької областей.

Діагностику пастерельозно-аскаридіозного мікст захворювання птиці проводили, враховуючи анамнестичні і епізоотологічні дані, клінічні ознаки, патологоанатомічні зміни, бактеріологічні дослідження. Кліні- 
чно обстежено 10000 голів птиці. Проведено патологоанатомічний розтин 1662 трупів загиблої птиці.

Проводили посіви із паренхіматозних органів (серця, печінки, селезінки) і червоного кісткового мозку на прості, збагачені та диференційно-діагностичні живильні середовища. Бактеріологічні дослідження проводили загальноприйнятими в мікробіології методами. Біологічну пробу проводили на лабораторних тваринах і птиці за загальноприйнятими методиками.

Аналізували результати епізоотологічних обстежень, які проводили у птахогосподарствах різних форм власності.

Клінічно хвору птицю на пастерельозноаскаридіозне мікст захворювання виявляли при клінічних оглядах птахопоголів'я.

Паразитологічні зажиттєві дослідження проводили гельмінтоскопією проб посліду.

Мета роботи полягала у вивченні впливу умовно патогенної мікрофлори на патологічний процес за пастерельозно-аскаридіозного мікст захворювання птиці патолого-анатомічним і бактеріологічним методами.

\section{Результати та їх обговорення}

За патолого-анатомічного розтину трупів загиблої птиці при контамінації умовно патогенною мікрофлорою відмічали нехарактерні зміни за пастерельозноаскаридіозного мікст захворювання: виснаження, кон'юнктивіт, виділення із носової порожнини мутного слизу, гідроперикардит, катаральна пневмонія, перигепатит, спленіт, катарально-геморагічний ентероколіт, геморагічний дуоденіт, клоацит, пір'я скуйовджене, тьмяне, навколо клоаки забруднене послідом темно-сірого кольору, інколи з домішками фібрину, суглоби потовщені, в суглобовій піхві накопичення ексудату солом'яно-жовтого кольору.

У півнів інколи відмічали ціаноз гребеня, в індиків - ціанотичність похідних шкіри голови, голубів і папуг - інтенсивне виснаження, збільшення селезінки в два рази.

Найбільш високій ураженості підлягали такі органи: серце, печінка, тонкий і товстий відділи кишечнику, суглоби.

При проведенні бактеріологічних досліджень патологічного матеріалу відібраного від загиблої птиці за пастерельозно-аскаридіозного мікст захворювання виділена така умовно патогенна мікрофлора (табл. 1).

Табличя 1

Результати бактеріологічних досліджень патологічного матеріалу від 358 трупів загиблої птиці

\begin{tabular}{|l|l|c|c|}
\hline \multicolumn{1}{|c|}{$\begin{array}{c}\text { Виділений } \\
\text { мікроорганізм }\end{array}$} & $\begin{array}{c}\text { Вид патологічного матеріа- } \\
\text { лу }\end{array}$ & $\begin{array}{c}\text { Кількість дослідже- } \\
\text { них проб }\end{array}$ & $\begin{array}{c}\text { Кількість позитив- } \\
\text { них проб }\end{array}$ \\
\hline Escherichia coli & $\begin{array}{l}\text { Серце, печінка, червоний } \\
\text { кістковий мозок }\end{array}$ & 261 & 223 \\
\hline Proteus vulgaris & Серце, печінка, селезінка & 27 & 18 \\
\hline Enterococcus faecalis & Серце, печінка, селезінка & 44 & 12 \\
\hline Staphylococcus gallinarum & $\begin{array}{l}\text { Серце, печінка, селезінка } \\
\text { червоний кістковий мозок }\end{array}$ & 16 & 4 \\
\hline Lactobacterium spp. & Серце, печінка & 10 & 2 \\
\hline
\end{tabular}

Наведені результати бактеріологічних досліджень патологічного матеріалу від загиблої птиці свідчать, що найбільш поширеним із патогенних мікроорганізмів була Escherichia coli, яка складала 85,4\%, Proteus vulgaris - 66,7\%, Enterococcus faecalis - 27,2\%, Staphylococcus gallinarum - 25\%, Lactobacterium spp. - 20\%. Найчастіше виділяли умовно патогенну мікрофлору із паренхіматозних органів: серця, печінки, селезінки та червоного кісткового мозку. Тому слід відмітити, що виділені патогенні мікроорганізми відіграють важливу роль у розвитку і ускладненні патологічного процесу за пастерельозно-аскаридіозного мікст захворювання у птиці.

При проведенні клінічних оглядів птахопоголів'я за епізоотологічних обстежень птахогосподарств різних форм власності спостерігали стрімке зростання спалахів пастерельозно-аскаридіозного мікст захворювання птиці, ускладненого умовно патогенною мікрофлорою навесні та восени. Динаміка зміни кількості спалахів мікст захворювання та інтенсивної загибелі птиці наведена на рис. 1. При цьому склад патогенних мікроорганізмів за пастерельозноаскаридіозного мікст захворювання птиці мав певні сезонні коливання.

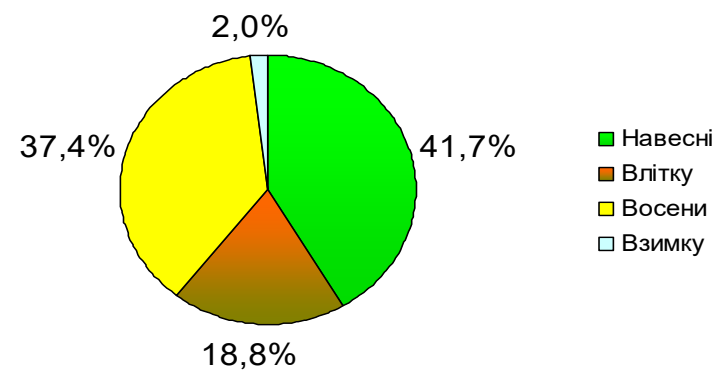

Рис. 1. Частота виділення умовно патогенної
мікрофлори за виникнення пастерельозно-
аскаридіозного мікст захворювання

Так, залежно від пори року змінювалися склад і кількість мікроорганізмів, які ускладнювали мікст захворювання, коливався. Навесні їх реєстрували частіше до $41,7 \%$, восени до $37,4 \%$, тимчасом як в літку до $18,8 \%$ та взимку до $2 \%$.

Навесні за рахунок неповноцінної годівлі, жорсткої схеми імунізації у птиці знижується резистентність організму і на цьому фоні найбільш інтенсивно активується умовно патогенна мікрофлора, яка пригнічує імунну систему птиці і посилює патологічний 
процес за пастерельозно-аскаридіозного мікст захворювання.

\section{Висновки}

1. Найчастіше виділення умовно патогенної мікрофлори за пастерельозно-аскаридіозного мікст захворювання відмічали навесні - до 41,7\%. 3'ясували, що найбільш поширеною із патогенних мікроорганізмів була Escherichia coli, яка складала 85,4\%.

2. Патолого-анатомічні зміни за пастерельозноаскаридіозного мікст захворювання, ускладненого умовно патогенною мікрофлорою були нехарактерними.

3. Виділені патогенні мікроорганізми відіграють важливу роль у розвитку і ускладненні патологічного процесу за пастерельозно-аскаридіозного мікст захворювання птиці.

\section{Бібліографічні посилання}

Apatenko, V.M. (2009). Parazitocenozy v patomorfologicheskom aspekte. Visnik SNAU. 6(25), 7-11 (in Russian).

Bondarenko, V.M. (1999). Faktory patogennosti bakterij i ih rol' $\mathrm{v}$ razvitii infekcionnogo processa. Zhurnal mikrobiologii, epidemiologii i immunologii. 5, 34-38 (in Russian).

Akulov, A.V. (1978). Patologoanatomicheskaja diagnostika boleznej ptic. M.: Kolos, 115-126 (in Russian).

Bajdevljatov, A.B., Bessarabov, B.F., Sjurin, V.N. (1980). Spravochnik po boleznjam sel'skohozjajstvennyh ptic. K.: Urozhaj, 36-98 (in Russian).

Berezovskyi, A.V. (2012). Khvoroby ptytsi: navchalnyi posibnyk. K.: DIA (in Ukrainian).
Herman, V.V. (2002). Dovidnyk z khvorob ptytsi. Kh.: Folio (in Ukrainian).

Korniienko, L.Ie., Nalyvaiko, L.I., Nedosiekov, V.V. (2012). Infektsiini khvoroby ptytsi. Kherson.: Hrin D.S. (in Ukrainian).

Korovin, R.N. (1995). Spravochnik veterinarnogo vracha pticevodcheskogo predprijatija. Sankt-Peterburg. 1, 3 (in Russian).

Labinskaja, A.S. (1978). Mikrobiologija s tehnikoj mikrobiologicheskih issledovanij. M. «Medicina» (in Russian).

Golovko, A.N., Ushkalov, V.A., Skripnik, V.G., Stegnij, B.T. (2007). Mikrobiologicheskie i virusologicheskie issledovanija $v$ veterinarnoj medicine. Spravochnoe posobie. NTMG (in Russian).

Hult, Dzh., Krig, N., Snit, P. (1997). Opredelitel' bakterij Berdzhi. M.: Mir (in Russian).

Plys, V.M. (2017). Mikst pasterelozno-askarydiozne zakhvoriuvannia ptytsi. Dnipro.: «Zhurfond» (in Ukrainian).

Plys, V.M., Shendryk, L.I. (2014). Epizootolohichnyi monitorynh ta patolohoanatomichni zminy za pasterelozu (kholery) ptytsi $\mathrm{v}$ asotsiatsii $\mathrm{z}$ deiakymy invaziiamy. Naukovyi visnyk Lvivskoho natsionalnoho universytetu veterynarnoi medytsyny ta biotekhnolohii imeni S.Z. Gzhytskoho. 16, 2(59), 262-270 (in Ukrainian).

Plys, V.M., Fotina, T.I. (2014). Epizootolohichnyi monitorynh, klinichni oznaky ta patolohoanatomichni zminy za pasterelozu (kholery) ptytsi v asotsiatsiiakh z deiakymy infektsiinymy ta invaziinymy zakhvoriuvanniamy. Visnyk Sumskoho natsionalnoho ahrarnoho universytetu. 6(35), 114-122 (in Ukrainian). Received 4.09.2017 Received in revised form 13.10.2017 Accepted 20.10.2017 